\title{
Non-Lethal Effects of $N$-Acetylcysteine on Xylella fastidiosa Strain De Donno Biofilm Formation and Detachment
}

\author{
Cristina Cattò ${ }^{1}{ }^{\circledR}$, Luca De Vincenti ${ }^{1}$, Francesca Cappitelli ${ }^{1} @$, Giusy D'Attoma ${ }^{2}$, \\ Maria Saponari $^{2}\left(\mathbb{D}\right.$, Federica Villa ${ }^{1, *}$ (D) and Fabio Forlani $^{1}$ \\ 1 Department of Food, Environmental and Nutritional Sciences, Università degli Studi di Milano, \\ via Celoria 2, 20133 Milano, Italy; cristina.catto@unimi.it (C.C.); luca.devincenti@unimi.it (L.D.V.); \\ francesca.cappitelli@unimi.it (F.C.); fabio.forlani@unimi.it (F.F.) \\ 2 Institute for Sustainable Plant Protection, Consiglio Nazionale delle Ricerche, via Amendola 165/A, \\ 70126 Bari, Italy; giusy.dattoma@ipsp.cnr.it (G.D.); maria.saponari@ipsp.cnr.it (M.S.) \\ * Correspondence: federica.villa@unimi.it; Tel.: +39-02-503-19121
}

Received: 11 October 2019; Accepted: 3 December 2019; Published: 5 December 2019

\begin{abstract}
This study investigated in-vitro the non-lethal effects of $N$-acetylcysteine (NAC) on Xylella fastidiosa subspecies pauca strain De Donno (Xf-DD) biofilm. This strain was isolated from the olive trees affected by the olive quick decline syndrome in southern Italy. Xf-DD was first exposed to non-lethal concentrations of NAC from 0.05 to $1000 \mu \mathrm{M}$. Cell surface adhesion was dramatically reduced at $500 \mu \mathrm{M}$ NAC $(-47 \%)$, hence, this concentration was selected for investigating the effects of pre-, postand co-treatments on biofilm physiology and structural development, oxidative homeostasis, and biofilm detachment. Even though $500 \mu \mathrm{M}$ NAC reduced bacterial attachment to surfaces, compared to the control samples, it promoted Xf-DD biofilm formation by increasing: (i) biofilm biomass by up to $78 \%$ in the co-treatment, (ii) matrix polysaccharides production by up to $72 \%$ in the pre-treatment, and (iii) reactive oxygen species levels by 3.5-fold in the co-treatment. Xf-DD biofilm detachment without and with NAC was also investigated. The NAC treatment did not increase biofilm detachment, compared to the control samples. All these findings suggested that, at $500 \mu \mathrm{M}, \mathrm{NAC}$ diversified the phenotypes in Xf-DD biofilm, promoting biofilm formation (hyper-biofilm-forming phenotype) and discouraging biofilm detachment (hyper-attachment phenotype), while increasing oxidative stress level in the biofilm.
\end{abstract}

Keywords: $\mathrm{N}$-acetylcysteine; non-lethal concentration; biofilm formation; Xylella fastidiosa strain De Donno; detachment

\section{Introduction}

Xylella fastidiosa is a bacterium that infects more than 500 different plants including ornamental plants, landscape trees, wild and crop species [1,2]. Serious economic losses caused by X.-fastidiosa-related epidemic diseases in valuable crops have been well documented [3]. The first field outbreak of X. fastidiosa in the European Union dated back in October 2013, when the Italian Phytosanitary Authorities reported the presence of this quarantined pathogen in southern Italy's olive orchards [4]. The novel X. fastidiosa-related disease called olive quick decline syndrome (OQDS), known to cause severe leaf scorth and branch dieback, poses one of the most debilitating threats to the European agriculture and landscape [5,6]. X. fastidiosa subspecies pauca strain De Donno (Xf-DD) was recovered in 2014 from OQDS-affected olive trees. Its complete genome has been sequenced [7] and the pathogenicity on the olive trees and other susceptible hosts was confirmed by needle inoculations [8]. 
The major pathogenic mechanism of X. fastidiosa relies on the obstruction of xylem vessels caused by biofilm formation $[9,10]$. A biofilm is a complex community of microorganisms that are attached to surfaces (in this case, on the cuticular lining of the insect foregut and/or the wall of the xylem), embedded in a self-produced matrix of hydrated extracellular polymeric substances, EPS [11]. Within the biofilm, the cells coordinate their behavior and function to survive and to persist in their environment. Biofilm formation in the insect foregut is closely associated with the acquisition, retention and transmission of the phytopathogen by sharpshooter vectors [12]. While in plants, the biofilm clogs the xylem vessels, depriving the plants of water and nutrition, and ultimately leading them to their death [13].

So far, there has been neither a therapy to cure Xylella-associated diseases nor a strategy to contain its impact. The spread of the disease is minimized by simply removing the infected plants and reducing the vector populations [1]. However, intense research programs are ongoing worldwide to search for remedies for this bacterial infection, which include, but are not limited to, the search for natural enemies to control the vectors [14,15], the production of transgenic plants [16] and the induction of plant defense responses [17].

Other studies have reported some strategies that directly target the pathogen to reduce its spread inside the plant. These strategies are aimed to kill the phytopathogen by using specific phages that are able to lysate X. fastidiosa cells [18], antibiotics such as tetracyclines [19,20], metal compounds like copper-zinc fertilizers [21,22], and some natural products such as polyphenols, azadirachtin A, hesperidin and radicinin [23-25].

Among natural bioactive molecules, $\mathrm{N}$-acetylcysteine (NAC), a thiol-containing compound commonly found in Allium plants, has shown interesting antibiofilm activities in clinical settings [26-28]. Muranaka et al. [29] and Picchi et al. [30] reported promising results in treating X. fastidiosa strain $9 \mathrm{a} 5 \mathrm{c}$, isolated from citrus variegated chlorosis (CVC) symptomatic sweet orange trees, and other phytopathogenic bacteria with lethal NAC concentrations. In-vitro studies have shown that concentrations of NAC of 1.0, 2.0 and $6.0 \mathrm{mg} / \mathrm{mL}$ affect $X$. fastidiosa strain $9 \mathrm{a} 5 \mathrm{c}$ adhesion to glass surfaces and EPS amount, consequently reducing the biofilm biomass [29]. The reduction in biofilm formation was correlated to the reduction in the number of viable cells, suggesting that even the lowest NAC concentration tested $(1 \mathrm{mg} / \mathrm{mL})$ had a biocidal effect on X. fastidiosa strain 9a5c [29]. In-vivo experiments have revealed that orange plants treated with lethal concentrations of NAC supplied in hydroponics and fertigation systems, as well as adsorbed in organic fertilizer, display significant CVC symptom remission and bacterial population reduction [29].

Despite the encouraging results, the non-lethal effects of NAC on X. fastidiosa has never been investigated. This is an important aspect to be studied, because for each biocide treatment, the concentration of the biocide is reasonably expected to diminish over time and space, resulting in a non-lethal level away from the application point. The physiological and behavioral responses of $X$. fastidiosa biofilm at this low concentration may be different from those at biocidal concentrations.

With these considerations, the main goal of this study was to investigate in-vitro the non-lethal effects of NAC on X. fastidiosa subspecies pauca strain De Donno (Xf-DD) biofilm, originally isolated from OQDS-affected olive trees in southern Italy. After the response of Xf-DD to a range of non-lethal concentrations was screened, $500 \mu \mathrm{M}$ NAC showed the highest effect on reducing the number of cells attached to surfaces, and hence, this concentration was selected for further investigations. Additional biofilm experiments with $500 \mu \mathrm{M}$ NAC simulated three different treatments: (i) pre-treatment, where planktonic cells were treated with NAC before their attachment to the surface; (ii) post-treatment, where biofilm was grown in the presence of NAC after the attachment phase; and (iii) co-treatment, where planktonic and biofilm cells were exposed to NAC. For the first time, the effects of $500 \mu \mathrm{M}$ NAC on Xf-DD biofilm were studied, taking into consideration biofilm formation and detachment. To this end, biofilm physiology and structural development, modulation of oxidative homeostasis, and induction of biofilm dislodgment were investigated. 


\section{Materials and Methods}

\subsection{Bacterial Strain and Culture Conditions}

Xf-DD strain (CFBP 8402) was originally isolated in 2014 from a OQDS-affected olive tree (Olea Europaea cv Ogliarola) grown in the municipality of Gallipoli (Apulia region, southern Italy) [31]. The strain was obtained from olive cuttings on buffered charcoal yeast extract (BCYE) agar medium [32], then stored at $-80{ }^{\circ} \mathrm{C}$ in $50 \%$ glycerol and was routinely grown on PD3 medium for $8-10$ days at $28^{\circ} \mathrm{C}$.

\subsection{Chemical Compound}

$\mathrm{N}$-acetylcysteine (NAC) was purchased from Sigma-Aldrich (A7250, $\geq 99 \%$ purity grade). NAC was dissolved in deionized water at room temperature to a concentration of $5000 \mu \mathrm{M}$. After adjusting $\mathrm{pH}$ to 6.8 with sodium hydroxide $(1 \mathrm{M} \mathrm{NaOH})$, the stock solution was sterilized by filtration through a $0.22 \mu \mathrm{m}$ filter and diluted in PD3 medium to the final concentrations of 1000, 500, 250, 50, 5, 0.5 and $0.05 \mu \mathrm{M}$.

\subsection{Toxicity Assay in the Presence of NAC}

The ability of $1000 \mu \mathrm{M}$ of NAC to inhibit the planktonic growth of Xf-DD was investigated as previously reported by Kandel et al. [33], with some modification. Briefly, Xf-DD colonies grown on PD3 agar plates for $8-10$ days at $28^{\circ} \mathrm{C}$ were scraped and resuspended in one $\mathrm{mL}$ of PD3 broth. Ten $\mu \mathrm{L}$ of cell suspension were diluted in PD3 (initial optical density of 0.04 at $600 \mathrm{~nm}$ ) supplemented with 0 (negative control) and $1000 \mu \mathrm{M}$ of NAC to obtain a final volume of $200 \mu \mathrm{L}$. The suspensions were placed in transparent 96-well polystyrene-based microtiter plates (Thermo-Fisher Scientific, Waltham, MA, USA). The plates were incubated at $28^{\circ} \mathrm{C}$, with shaking at $150 \mathrm{rpm} / \mathrm{min}$. Growth curves were generated by measuring the optical density at $600 \mathrm{~nm}\left(\mathrm{OD}_{600}\right)$ every $24 \mathrm{~h}$ for 7 days using an Infinite F200 PRO microplate reader (TECAN, Mannedorf, Switzerland). The polynomial Gompertz model was used to fit the growth curves and the maximum specific growth $\left(\mathrm{OD}_{600} /\right.$ day $)$ was calculated using the GraphPad Prism software (version 5.0, San Diego, CA, USA). Experiments were repeated independently three times with at least six technical replicates per time.

\subsection{Xf-DD Adhesion in 96-Well Plates}

Xf-DD colonies grown on PD3 agar plates were scraped and resuspended in $2 \mathrm{~mL}$ of PD3 (optical density at $600 \mathrm{~nm}$ of 0.8 ). Sterile polystyrene 96-well plates containing $190 \mu \mathrm{L}$ PD2 per well supplemented with $0,1000,500,250,50,5,0.5$ and $0.05 \mu \mathrm{M}$ NAC were inoculated with $10 \mu \mathrm{L}$ of cell suspensions. After 1 day of incubation at $28^{\circ} \mathrm{C}$, the cells suspensions were removed, the wells rinsed 3 times with Milli-Q water and stained with $0.1 \%$ crystal violet to quantify the attached cells [34]. The stain was removed after $30 \mathrm{~min}$, the adhered cells were gently washed 3 times with Milli-Q water and the microtiter plate dried for $2 \mathrm{~h}$. Crystal violet was then solubilized with $200 \mu \mathrm{L}$ of $6: 4$ acetone:ethanol. The absorbance at $550 \mathrm{~nm}$ was read using the Infinite F200 PRO microplate reader (Tecan, Mannedorf, Switzerland). All experiments were replicated at least three times.

\subsection{Xf-DD Biofilm Growth at the Solid/Air Interface}

Xf-DD biofilm was grown on a transwell device as previously described by Garuglieri et al. [35] with some modifications. Briefly, Xf-DD colonies grown on PD3 agar plates were scraped and resuspended in $2 \mathrm{~mL}$ of PD3 broth without (-) and with $500 \mu \mathrm{M}$ of NAC (NAC). After $24 \mathrm{~h}$ of incubation at $28{ }^{\circ} \mathrm{C}$ under agitation at $140 \mathrm{rpm}, 50 \mu \mathrm{L}$ of bacterial broth culture $(0.5$ optical density at $600 \mathrm{~nm})$ were inoculated at the center of a sterile polycarbonate membrane (Whatman Nucleopore, diameter $2.5 \mathrm{~cm}$, pore diameter $0.2 \mu \mathrm{m}$ ) and, once the inoculum was completely dried, the membrane was carefully transferred to a transwell device (ThinCertTM Cell Culture Inserts with translucent PET membrane-Greiner Bio-One, Kremsmünster, Austria) inlaid in a 6 well culture plate (Greiner Bio-One, 
Kremsmünster, Austria). One mL of PD3 medium without (-) and in the presence of $500 \mu \mathrm{M}$ of NAC (NAC) was added to inoculate the plate well. Mediums were replaced every $24 \mathrm{~h}$. Biofilms were grown at $28{ }^{\circ} \mathrm{C}$ for $72 \mathrm{~h}$.

Xf-DD biofilm was grown in four different conditions (Figure 1): (1) both planktonic and biofilm cells grown without NAC (named -/-), negative control; (2) planktonic cells treated with $500 \mu \mathrm{M}$ NAC and biofilm cells grown without NAC (named NAC/-), pre-treatment; (3) planktonic cells grown without NAC and biofilm cells grown with $500 \mu \mathrm{M}$ NAC (named -/NAC), post-treatment; (4) both planktonic and biofilm cells grown with $500 \mu \mathrm{M}$ of NAC (named NAC/NAC), co-treatment. After 7 days, biofilms obtained from each treatment were collected for further analyses.

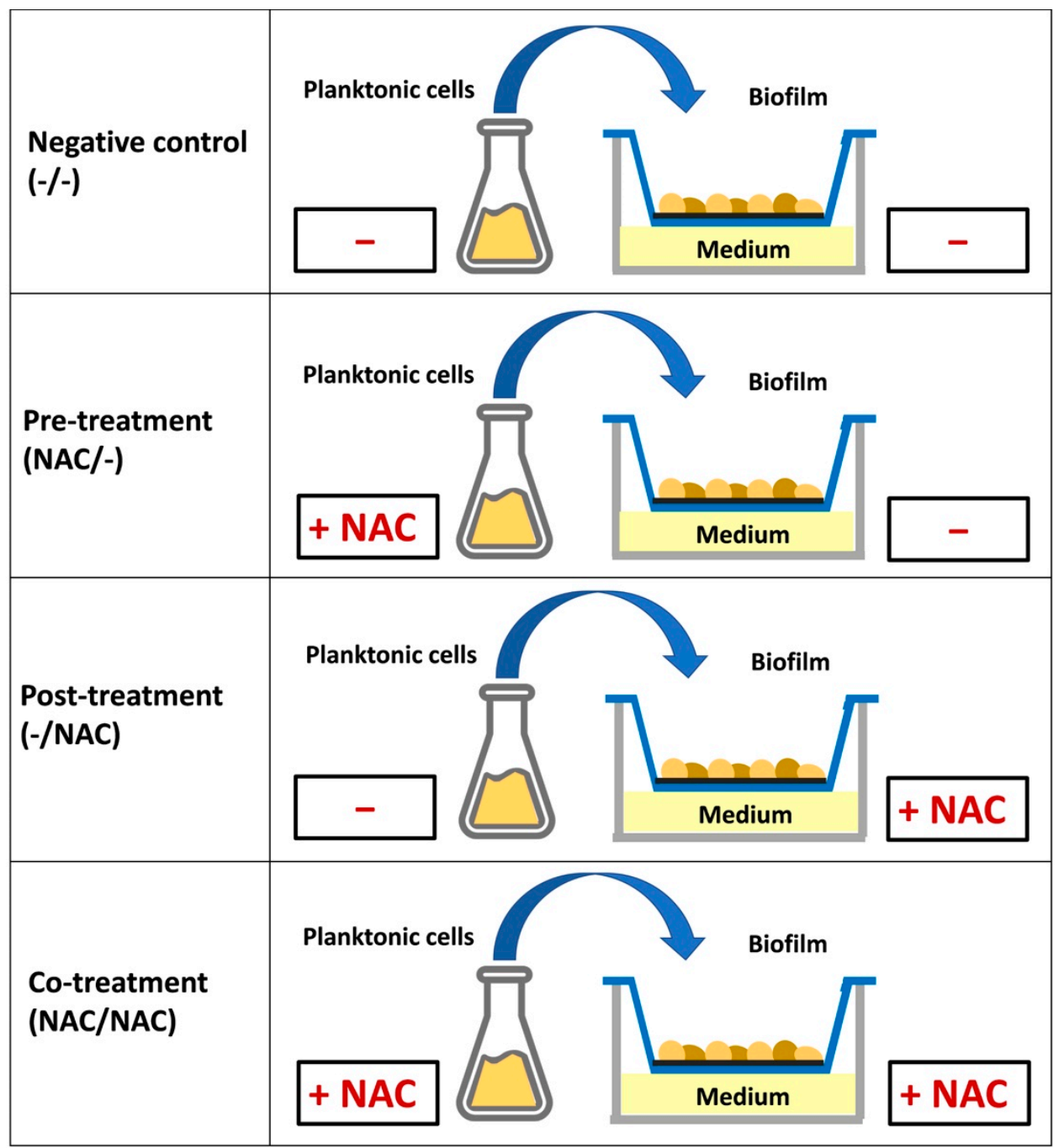

Figure 1. $N$-acetylcysteine (NAC) treatments used in this study. -/-: control, both planktonic and biofilm cells grown without NAC; NAC/-: pre-treatment, only the planktonic cells grown with NAC; -/NAC: post-treatment, only the biofilm cells grown with NAC; NAC/NAC: co-treatment, both planktonic and biofilm cells grown with NAC.

\subsection{Biofilm Biomass Quantification}

Biofilm biomass was evaluated measuring the amount of cellular protein [36]. Briefly, two membranes for each treatment were transferred in $1 \mathrm{~mL}$ of phosphate buffered saline solution (PBS), and biofilm was removed from the membrane surface by 1 min vortex mixing, 2 min sonication (50\% amplitude, in a water bath; Branson 3510, Branson Ultrasonic Corporation, Dunburry, CT, USA) followed by another $1 \mathrm{~min}$ of vortex mixing. Membranes were subsequently removed from 
the suspension and cells were broken by sonication (three cycles of $30 \mathrm{~s}$ at $40 \%$ power sonication with 15 s intervals; Branson 3510, Branson Ultrasonic Corporation, Dunburry, CT, USA) followed by centrifugation $\left(15 \mathrm{~min}\right.$ at $4{ }^{\circ} \mathrm{C}$ at $\left.5700 \times g\right)$. The supernatant was collected and the protein amount was quantified by Bradford assay [37] using bovine serum albumin as standard. Obtained data were normalized against the membrane area, and the means reported. The experiments were repeated three times with at least three technical replicates.

\subsection{Live/Dead Biofilm Assay}

Seven-day biofilms grown on the membrane in the transwell devices were transferred in $1 \mathrm{~mL}$ of Milli-Q water. Biofilms were dislodged from the membranes and cells were broken as reported in the section 'Biofilm biomass quantification'. The Live/Dead BacLight viability kit (Molecular Probes-Life Technologies, Carlsbad, CA, USA) was used to detect live and dead cells according to the manufacturer's instructions. The fluorescence intensity was measured using the Infinite 200 PRO Microplate Reader (Tecan, Manneford, Switzerland) with excitation at $480 \mathrm{~nm}$ and emission at $516 \mathrm{~nm}$ for the live green cells, and excitation at $581 \mathrm{~nm}$ and emission at $644 \mathrm{~nm}$ for the red dead cells. Fluorescence intensity was normalized by the proteins within the biofilm, divided for the area of the membrane, and the means reported. Relative viability within the biofilms was calculated by dividing the fluorescent intensity of normalized live cells by the fluorescent intensity of normalized dead cells in each sample. Experiments were repeated three times with at least six technical replicates per time.

\subsection{Confocal Laser Scanning Microscope (CLSM)}

Three-dimensional morphology of seven day-biofilms from each treatment were analyzed by CLSM. The biofilms were stained with Sybr green I fluorescent nucleic acid dye (S7563, Thermo Fisher Scientific, Waltham, MA, USA) to reveal biofilm cells. The staining was performed by incubating the biofilm with $200 \mu \mathrm{L}$ of 1:1000 Sybr green I dye solution in PBS at room temperature in the dark for $30 \mathrm{~min}$, and then rinsed with PBS. Membranes without biofilms were also stained in order to exclude any false positive signals. Each biofilm sample was visualized using a Nikon A1 with excitation at $488 \mathrm{~nm}$ line, and emission at 500 to $550 \mathrm{~nm}$ (green channel). Images were captured with a 100× oil immersion objective and analyzed with the software Fiji [38].

\subsection{Extraction and Characterization of the Extracellular Polymeric Substances (EPS) Matrix}

Seven day-biofilms from each treatment were analyzed for their EPS proteins and polysaccharides content. EPS extraction was performed as reported by Villa et al. [39]. The Bradford and the phenol-sulfuric acid $[37,40]$ methods were applied for quantification of proteins and polysaccharides using bovine serum albumin and glucose as standard, respectively. Obtained data were normalized by the area and the means reported. The EPS-polysaccharide/EPS-protein ratios were also calculated. The experiments were repeated three times with at least six technical replicates per time.

\subsection{Oxidative Stress Assay}

Seven day-biofilms from each treatment were transferred in $1 \mathrm{~mL}$ of $50 \mathrm{mM}$ PBS and the biofilm was detached from the membranes by vortex mixing and sonication as described above in the section 'Biofilm Biomass Quantification'. The suspension was centrifuged for $20 \mathrm{~min}$ at $11,000 \times \mathrm{g}$. The supernatant was transferred to another tube, filtered $(0.22 \mu \mathrm{m}$ pores size $)$ and analyzed for the extra-cellular ROS content. The pellet was resuspended in $50 \mathrm{mM}$ PBS, cells were broken by sonication as described previously in the section 'Biofilm Biomass Quantification', and the intra-cellular ROS content was quantified. Intra- and extra-cellular oxidative stresses were quantified using the ROS sensitive probe 2,7-dichlorofluorescein-diacetate according to Jakubowski et al. [41]. Fluorescence was measured using a microplate reader (Tecan, Manneford, Switzerland) at excitation wavelength of 485 $\mathrm{nm}$ and emission wavelength of $535 \mathrm{~nm}$. Obtained data were normalized by the protein within the 
biofilm, divided for the area, and the means reported. Experiments were repeated three times with at least five technical replicates per time.

\subsection{Biofilm Dispersion}

Membranes with biofilms grown for 7 days under the different treatments were transferred in petri dishes $(\varnothing 60 \mathrm{~mm}$ ) and incubated with $2 \mathrm{~mL}$ of phosphate buffered saline solution (PBS, Sigma-Aldrich, $\mathrm{pH} 6.8$ adjusted by potassium hydroxide) or $500 \mu \mathrm{M}$ NAC for further $24 \mathrm{~h}$ at $28^{\circ} \mathrm{C}$. Subsequently, biofilms on the membranes and those dislodged in the bulk liquid were analyzed for their biomass and the level of ROS as previously described in 'Biofilm Biomass Quantification' and 'Oxidative Stress Assay'. The detachment index was calculated as: (protein amount in the detached biofilm $\times$ $100) /($ protein amount detached biofilm + protein amount in the biofilm on the membrane). Experiments were repeated independently three times with at least four technical replicates per time.

\subsection{Statistical Analysis}

Two-tailed ANOVA and Student's $t$-test analysis, via a software run in MATLAB environment (Version 7.0, The MathWorks Inc., Natick, MA, USA), were applied to statistically evaluate any statistically significant differences among the samples. ANOVA and Student's $t$-test analysis were carried out after verifying data independence (Pearson's chi-square test), normal distribution (D'Agostino-Pearson normality test) and homogeneity of variance (Bartlett's test). Tukey's honestly significant different test (HSD) was used for pairwise comparison to determine the significance of the data. Statistically significant results were depicted by $p$-values $\leq 0.05$.

\section{Results}

\section{1. $1000 \mu M$ NAC Did Not Affect Xf-DD Planktonic Growth}

Figure 2a shows the 7 day-growth curves of Xf-DD in the presence and absence of $1000 \mu \mathrm{M}$ NAC. The results indicated no statistically significant differences on the maximum specific growth rate $\left(\mathrm{OD}_{600} /\right.$ day) between the NAC-treated samples $\left(0.218 \pm 0.01 ; \mathrm{R}^{2}=0.986\right)$ and control samples $(0.234 \pm$ $\left.0.02 ; R^{2}=0.972\right)$. Therefore, $1000 \mu \mathrm{M}$ NAC was considered a non-lethal concentration.
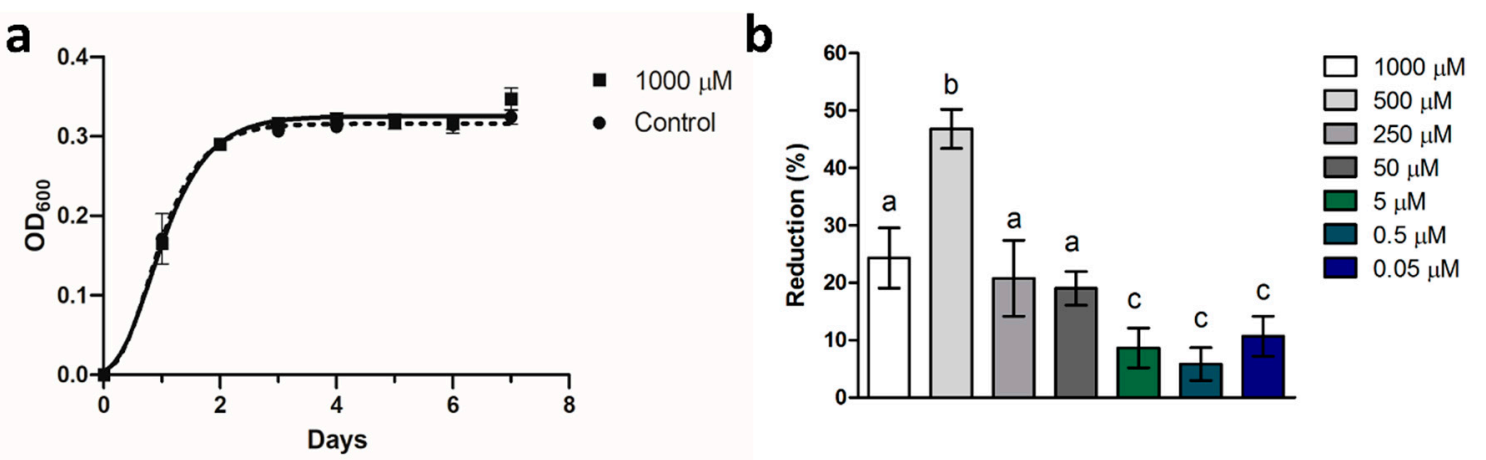

Figure 2. (a) $\mathrm{OD}_{600}$ values and Gompertz growth curves of Xylella fastidiosa subspecies pauca strain De Donno (Xf-DD) without and with $1000 \mu \mathrm{M}$ NAC. Data represent the mean \pm SD of three independent measurements. (b) Percentage of inhibition of Xf-DD attachment exposed to non-lethal concentrations of NAC. Data represent the mean \pm SD of three independent measurements. Different superscript letters indicate statistically significant differences (Tukey's honestly significant different test (HSD), $p \leq 0.05$ ) between conditions.

\subsection{Non-Lethal Concentrations of NAC Affected Xf-DD Adhesion in 96-Well Plates}

Figure $2 \mathrm{~b}$ displays the inhibition percentage of $\mathrm{Xf}-\mathrm{DD}$ adhesion induced by different non-lethal concentrations of NAC compared to the control samples. Although all the non-lethal concentrations 
affected Xf-DD attachment, $500 \mu \mathrm{M}$ NAC showed the highest effects of reducing cell adhesion by $47 \%$. The non-lethal concentration of $500 \mu \mathrm{M}$ NAC was used in the subsequent studies.

\subsection{NAC Treatments Increased Xf-DD Biofilm Biomass, While Not Affecting Cell Viability}

The effects of $500 \mu \mathrm{M}$ NAC on Xf-DD biofilm biomass were assessed by quantifying the protein amount within the biofilm. The data showed that $500 \mu \mathrm{M}$ NAC significantly increased the amount of biofilm proteins in all the treatments, compared to the control (Figure 3a), highlighting the maximum increase for the treatment NAC/NAC (78\%) and -/NAC (62\%), followed by NAC/- (22\%).
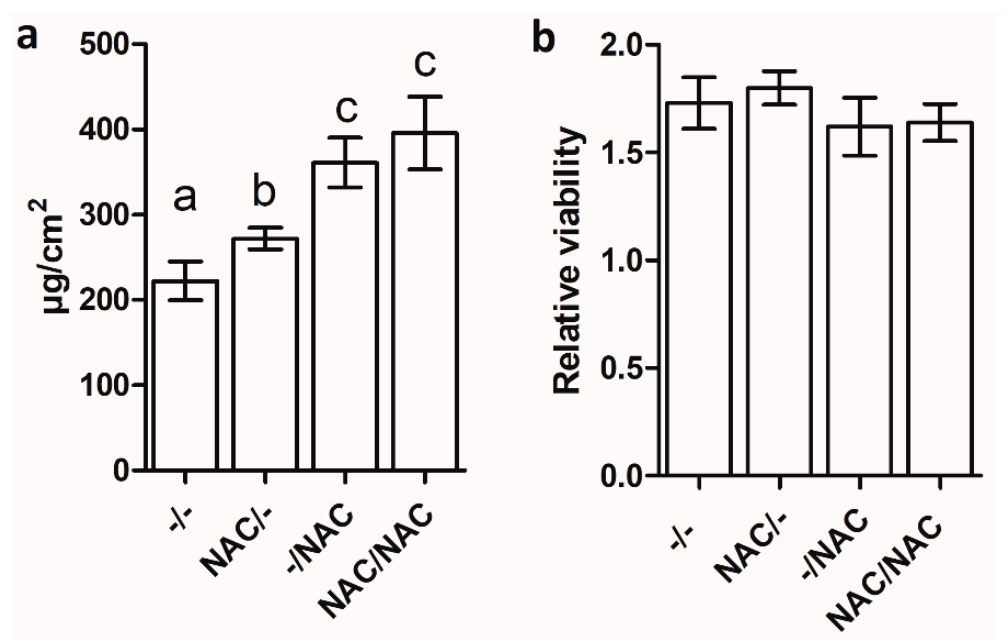

Figure 3. (a) Biofilm biomass expressed as protein amount of Xf-DD biofilm grown for 7 days under different conditions. (b) Relative viability of Xf-DD biofilm grown under different treatments. Data represent the mean $\pm \mathrm{SD}$ of three independent replicates. Different superscript letters indicate statistically significant differences (Tukey's HSD, $p \leq 0.05$ ) between conditions. $-/-$ : control, both planktonic and biofilm cells grown without NAC; NAC/-: pre-treatment, only the planktonic cells grown with NAC; -/NAC: post-treatment, only the biofilm cells grown with NAC; NAC/NAC: co-treatment, both planktonic and biofilm cells grown with NAC.

The Live/Dead viability assay was performed to verify the ability of NAC to affect biofilm viability. Relative viability calculated for each condition revealed no statistically significant differences among samples (Figure 3b).

Representative biofilm structures observed under different treatments are presented in Figure 4. Biofilm images were obtained by combining z-stack confocal image series with Fiji software. Control samples presented scattered cells and some small bacterial clusters. In all treated Xf-DD biofilms, the biomass increased, forming interconnected clusters with cells oriented horizontally and a few scattered cells were observed. 

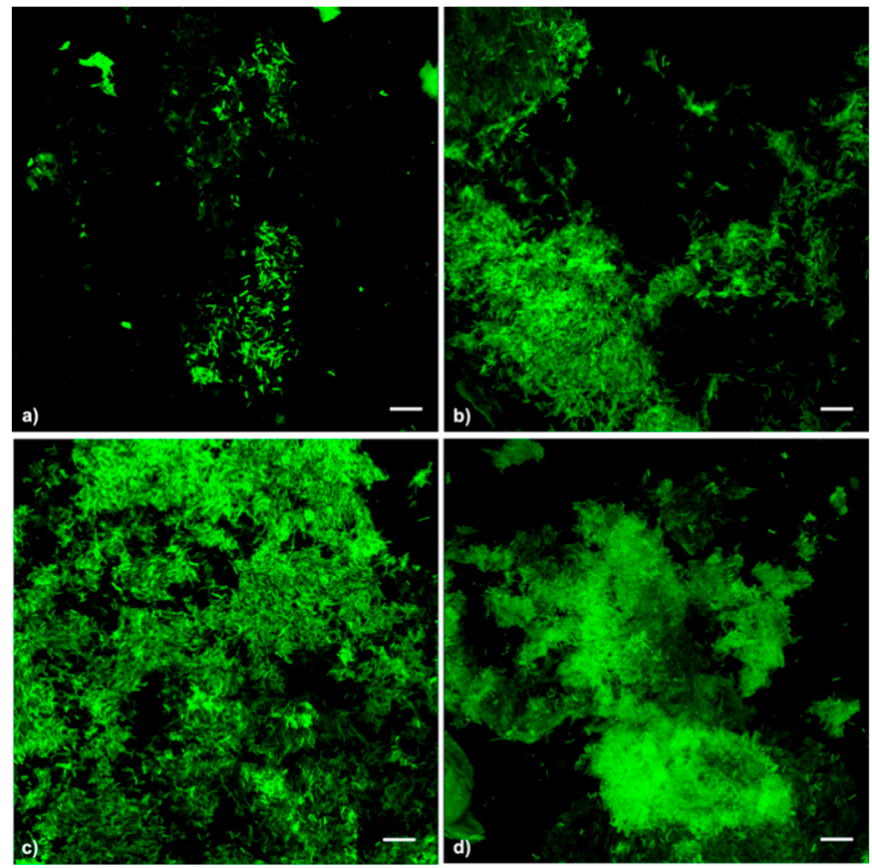

Figure 4. Confocal laser scanning imaging of Xf-DD biofilms under different treatments. (a), control; (b), pre-treatment; (c), post-treatment; (d), co-treatment. Scale bar: $10 \mu \mathrm{m}$.

\subsection{NAC Affected the Composition of the Extracellular Polymeric Substances (EPS)}

Figure 5a shows the quantification of EPS polysaccharides. The experiments revealed that NAC/and -/NAC were statistically significantly different compared to the control $-/-$, with the maximum increase for the treatment NAC/- (72\%), followed by - NAC (53\%) and NAC/NAC (26\%).
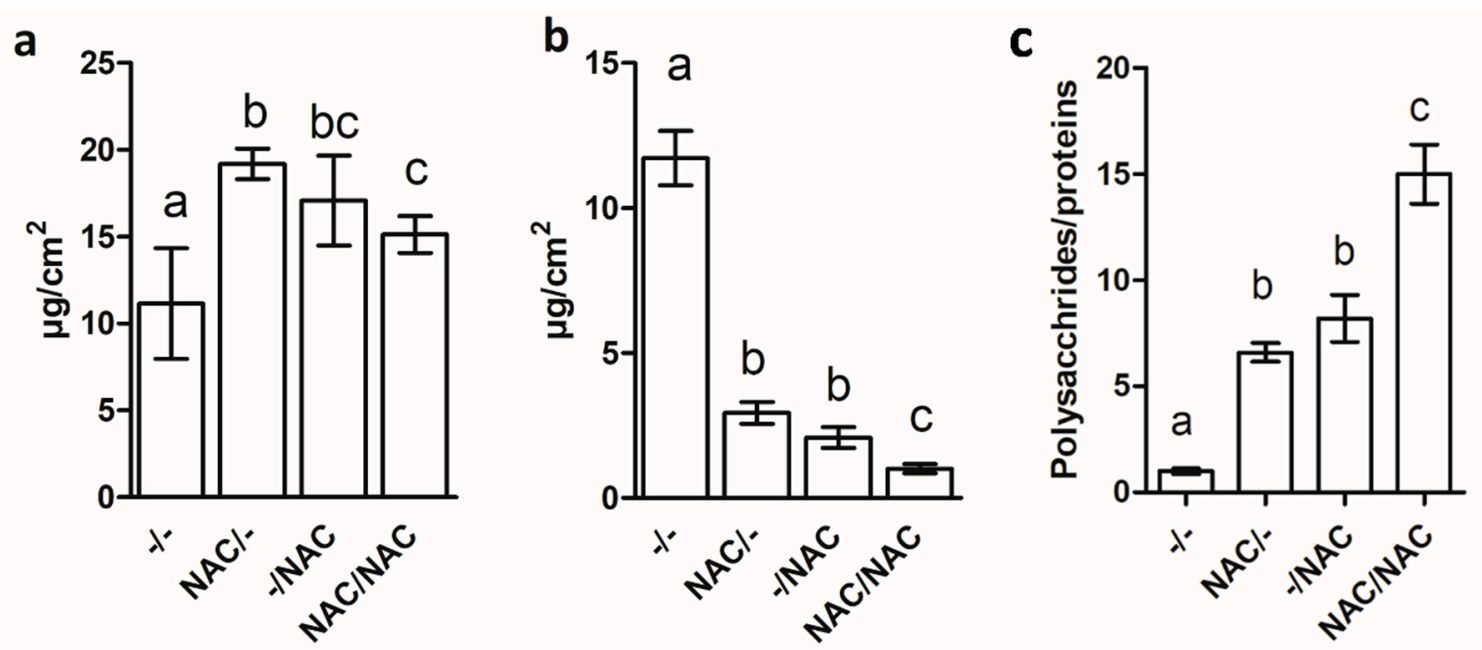

Figure 5. Polysaccharides (a) and proteins (b) amount in the extracellular polymeric substances (EPS) matrix of Xf-DD biofilm grown for 7 days under different treatments. Panel (c) displays the EPS polysaccharides/ EPS proteins ratios. Data represent the mean \pm SD of three independent biological replicates. Different superscript letters indicate statistically significant differences (Tukey's HSD, $p \leq 0.05$ ) between conditions. - - - control, both planktonic and biofilm cells grown without NAC; NAC/-: pre-treatment, only the planktonic cells grown with NAC;-/NAC: post-treatment, only the biofilm cells grown with NAC; NAC/NAC: co-treatment, both planktonic and biofilm cells grown with NAC. 
Figure $5 b$ shows the EPS protein amount. The charts show a statistically significant reduction in the protein amount in all the treatments, with the highest reduction for the treatment NAC/NAC (91\%), followed by $-/ \mathrm{NAC}(82 \%)$ and NAC/- (75\%).

Figure $5 \mathrm{c}$ displays the EPS polysaccharides/EPS proteins ratios. The graph indicated that NAC modulated the chemical composition of the biofilm matrix, with a shift toward the increase of exopolysaccharides versus the extracellular proteins. Indeed, the ratios increased in all the treatments, reaching the maximum increase for the NAC/NAC treatment (+14.7-fold).

\subsection{NAC Increased the Oxidative Stress within Xf-DD Biofilm}

Figure 6 shows that Xf-DD biofilms exposed to $500 \mu \mathrm{M}$ NAC were more prone to accumulate ROS, both intracellularly and extracellularly (in the EPS matrix). Intracellular levels of ROS (Figure 6a) showed the highest statistically significant increase compared to the control $-/-$ in the treatment NAC/NAC (3.5-fold), followed by NAC/- (2.8-fold) and -/NAC (2.6-fold).

a

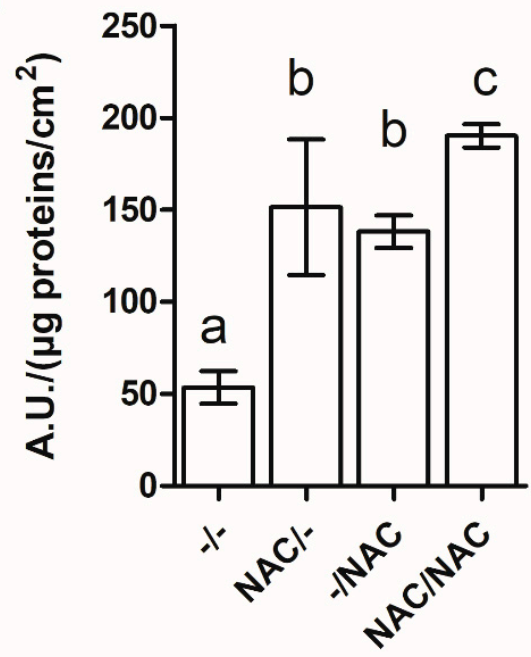

b

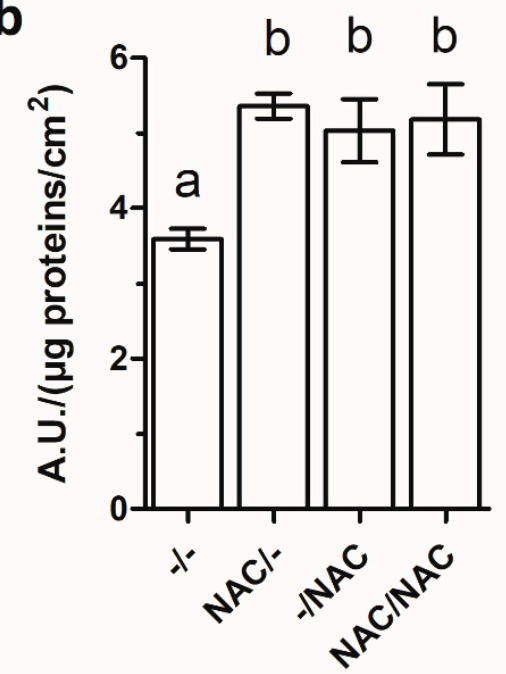

Figure 6. Intracellular (a) and extracellular (b) level of ROS within Xf-DD biofilm grown for 7 days under different conditions. Data represent the mean \pm SD of three independent biological replicates. Different superscript letters indicate statistically significant differences (Tukey's HSD, $p \leq 0.05$ ) between different conditions. -/-: control, both planktonic and biofilm cells grown without NAC; NAC/-: pre-treatment, only the planktonic cells grown with NAC;-/NAC: post-treatment, only the biofilm cells grown with NAC; NAC/NAC: co-treatment, both planktonic and biofilm cells grown with NAC.

Inside the EPS (Figure 6b), a statistically significant increase of ROS level compared with the control -/- was observed in all treatments, with the highest value reported for NAC/- (1.5-fold), followed by NAC/NAC (1.4-fold) and -/NAC (1.4-fold). No statistically significant differences resulted among the treatments.

\subsection{NAC Decreased Xf-DD Biofilm Detachment}

In order to study Xf-DD biofilm detachment after NAC treatments, an experiment was carried out in which mature biofilms, grown without and with NAC according to the pre-, post- and co- treatments, were soaked in both PBS and $500 \mu \mathrm{M}$ NAC. After $24 \mathrm{~h}$ the biomass remaining on the membrane surface and those released in the bulk liquid were quantified. The tendency towards biofilm detachment for the control Xf-DD biofilm soaked in PBS was 3-fold higher than that soaked in NAC, suggesting that NAC increased Xf-DD cell-cell adhesion (Figure 7). Comparing to the control samples soaked in PBS, none of the pre-, post- and co-treatments promoted biofilm detachment. 


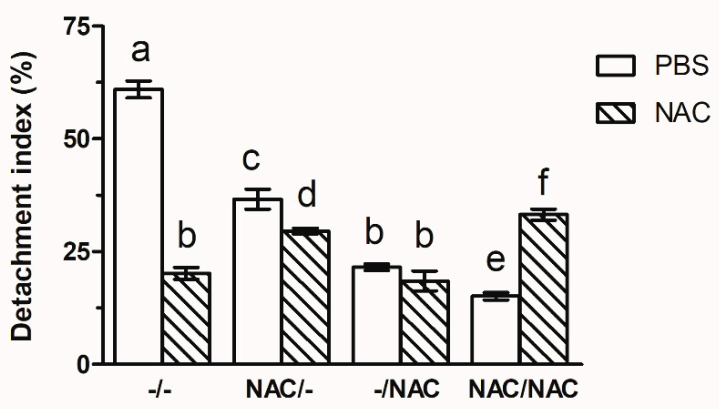

Figure 7. Detachment index of Xf-DD biofilm grown under different conditions after $24 \mathrm{~h}$ PBS or NAC treatment. Data represent the mean \pm SD of three independent biological replicates. Different superscript letters indicate statistically significant differences (Tukey's HSD, $p \leq 0.05$ ) between different conditions. -/-: control, both planktonic and biofilm cells grown without NAC; NAC/-: pre-treatment, only the planktonic cells grown with NAC; -/NAC: post-treatment, only the biofilm cells grown with NAC; NAC/NAC: co-treatment, both planktonic and biofilm cells grown with NAC.

\subsection{NAC Affected the Level of ROS after Biofilm Detachment}

After detachment experiments, the level of ROS was quantified in Xf-DD biomass remained on the membrane, in the biomass detached from the membrane and in the bulk liquid medium. The data revealed that the biomass retained on the membrane (Figure 8a) after soaking in $500 \mu \mathrm{M} \mathrm{NAC}$ was more prone to accumulate ROS in comparison to the corresponding ones soaked in PBS, with the maximum increase in the control treatment -/- (3.3-fold), followed by -/NAC (1.6-fold), NAC/NAC (1.6-fold) and NAC/- (1.2-fold). The bulk biomass displayed the same trend (Figure 8b). Indeed, the highest result was obtained for the treatment -/NAC (30.1-fold), followed by NAC/NAC (14.5-fold), -/- (9.0-fold) and $\mathrm{NAC}$ - (8.0-fold). ROS levels in the bulk liquid showed the highest statistically significant increase compared to the negative controls for the treatment -/- (67.2-fold), followed by NAC/- (44.5-fold), -/NAC (43.1-fold) and NAC/NAC (28.8-fold) (Figure 8c).

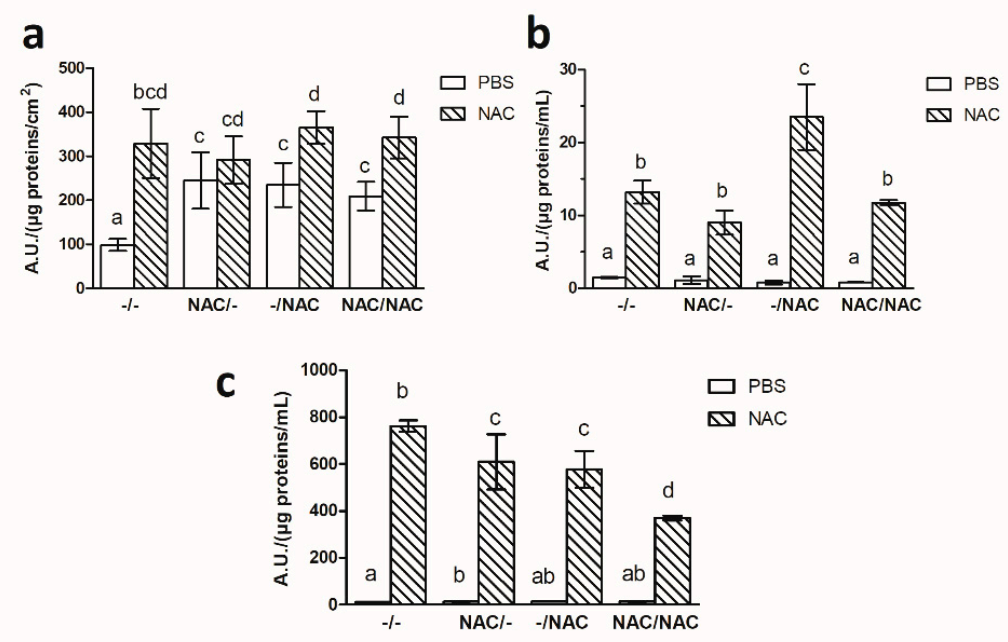

Figure 8. ROS levels within the biofilm remained on the membrane (a), detached from the membrane (b) and that in the bulk liquid (c) after $24 \mathrm{~h}$ in presence of phosphate buffered saline solution (PBS) or NAC. Data represent the mean \pm SD of three independent biological replicates. Different superscript letters indicate statistically significant differences (Tukey's HSD, $p \leq 0.05$ ) between different conditions -/-: control, both planktonic and biofilm cells grown without NAC; NAC/-: pre-treatment, only the planktonic cells grown with NAC; -/NAC: post-treatment, only the biofilm cells grown with NAC; NAC/NAC: co-treatment, both planktonic and biofilm cells grown with NAC. 


\section{Discussion}

Many in-vitro studies have demonstrated NAC antibiofilm activity against a variety of Gram-positive, such as Enterococcus faecalis and Staphylococcus aureus, and Gram-negative pathogenic bacteria such as Pseudomonas aeruginosa, Stenotrophomonas maltophilia and Burkholderia cepacia, as well as some yeasts [26,42-44]. Apart from its antibacterial effect, NAC at lethal concentrations reduces bacterial adhesion, inhibits extracellular polysaccharides production and promotes biofilm dispersion in skin pathogens and bacteria associated with chronic diseases in humans [45-47]. The encouraging in-vitro results obtained with NAC, the low cost, and the low toxicity to humans and the environment prompted Muranaka et al. [29] to test NAC against X. fastidiosa strain 9a5c isolated from symptomatic sweet orange trees. Indeed, both in-vitro and in-vivo findings indicated that NAC at lethal concentrations can be an effective strategy for attenuating the CVC symptoms in citrus. However, downstream from the treated area, there is likely to be a gradient of the biocide concentration, ranging from the prescribed concentration to virtually zero. The response of the plant pathogens to this low, non-lethal concentration of NAC was the impetus of this study.

For the first time, this work investigates the non-lethal effects of $500 \mu \mathrm{M}$ NAC on Xf-DD biofilm by simulating pre- (NAC/-), post- (-/NAC) and co- (NAC/NAC) treatments in-vitro. The $500 \mu \mathrm{M}$ NAC concentration was selected after screening the response of Xf-DD to a range of non-lethal NAC concentrations, where an NAC concentration of $500 \mu \mathrm{M}$ reduced Xf-DD surface adhesion by $47 \%$ in microtiter assays. Interestingly, the best anti-adhesion performance of NAC was obtained at the specific threshold level of $500 \mu \mathrm{M}$, which did not correspond to the maximum concentration tested. The non-linear response patterns depicted by the anti-adhesion assays followed a parabola-like shape profile resembling a hormetic property, a situation in which the response to a compound varies with the exposure level. A biphasic profile is common in the biofilm world $[48,49]$. For instance, antibiotics act in a concentration-dependent manner, where upper and lower threshold concentrations trigger the formation of a biofilm [50].

While microtiter techniques are more suitable for studying bacterial adherence to a surface, the static nature of these techniques has a tendency towards cell nutrient exhaustion that limits the generation of mature biofilm [51]. Therefore, to investigate the effects of the compound on mature biofilms, subsequent experiments on biofilm development and physiology using the transwell system were conducted at $500 \mu \mathrm{M}$ NAC. A dramatic increase in biofilm biomass was observed after the treatment of $500 \mu \mathrm{M} \mathrm{NAC}$, with a maximum increase of $78 \%$ in the co-treatment (NAC/NAC). BacLight assays demonstrated that the cells within the treated biofilms were viable, confirming the non-lethal activity of NAC. The increase in biofilm biomass under the NAC treatment was also corroborated by CLSM images, where the co-treatment (NAC/NAC) promoted the highest levels of Xf-DD biomass. It is worth noting that a reduced number of adhered cells did not guarantee a biofilm biomass reduction. Glasenapp et al. [36] observed that although sub-lethal concentrations of mangrove extracts reduced microbial adhesion to the surfaces, they stimulated EPS production with a consequent increase in biofilm biomass.

Moreover, biofilms exposed to NAC were more prone to accumulate both intracellular and extracellular ROS. Although NAC is well known for its antioxidant activity, it can act as a pro-oxidant under specific conditions [52]. NAC generates ROS in reactions with transition metals such as $\mathrm{Fe}^{3+}$, which is reduced to its catalytically-active form $\mathrm{Fe}^{2+}$. Furthermore, NAC can react with free radicals and become a thiyl radical itself [52,53]. In X. fastidiosa, ROS acted as an environmental cue that stimulated biofilm development during the early stage of plant colonization, such that the oxidative imbalance was actually required by X. fastidiosa to achieve maximum xylem colonization [54]. It has also been proved that $X$. fastidiosa biofilm is related to the sensing of a redox imbalance via the oxidative stress regulator OxyR [54,55]. In fact, oxyR mutants were impaired in their ability to attach to surfaces, to aggregate with other cells, and to consequently form biofilm. Thus, biofilm formation by $X$. fastidiosa might be an adaptive response to the exogenous oxidative stress normally encountered by the bacterium in the xylem vessels [54-57]. In line with the previous considerations, it seems likely 
that the non-lethal concentration of $500 \mu \mathrm{M}$ NAC increases the levels of ROS, providing the selective pressure for hyper-biofilm-forming phenotypes. Indeed, the increase in biofilm biomass upon exposure to NAC might have been an adaptive mechanism adopted by the bacteria to protect themselves from the deleterious effect of ROS. According to previous studies, several bacteria respond to sub-lethal doses of ROS by increasing biofilm formation [39,58-60]. The NAC promotion of biofilm formation was previously described by Yin et al. [61], where they showed an increasing biofilm formation in Staphylococcus aureus, Enterococcus faecalis, and Pseudomonas aeruginosa caused by the combination of NAC and serum transferrin. The authors demonstrated that biofilm potentiation is caused by a disturbance of the redox status in the bacterial cells. Eroshenko et al. [47] also found that S. aureus and E. faecalis biofilms increased when exposed to sub-lethal concentrations of NAC.

All NAC-treated samples showed an increase in the EPS polysaccharides/EPS proteins ratios. Indeed, the ratio was shown to increase with the protraction of NAC exposure, with ratios from 1:1 in the control biofilm to 15:1 in the case of NAC/NAC. This result suggests that increased exposure to sub-lethal NAC levels promoted polysaccharide production in the EPS matrix. Further, polysaccharides increase the cohesiveness of the biofilm thereby reducing detachment [62], as seen in our work. Accordingly, Olofsson et al. [63] reported a change in the polysaccharide composition of Klebsiella pneumoniae biofilm after being exposed to NAC. In addition, Yin et al. [61] showed an increase in the transcripts of the genes that control the production of extracellular polysaccharides in NAC-exposed S. aureus. The polysaccharide overproduction in the EPS matrix after NAC exposure could be related to the oxidative imbalance in the treated biofilm. It has been demonstrated that EPS polysaccharides played a critical role in relief of the oxygen stress in several microorganisms such as Pseudomonas putida, Sinorhizobium meliloti and Acinetobacter oleivorans [59,64-66]. Indeed, some polysaccharides can scavenge hydroxyl radicals, inhibiting lipid and protein oxidation $[67,68]$. Interestingly, the role of the redox-sensing transcription factor OxyR in the regulation of EPS exopolysaccharide production has been reported $[65,69]$. Burbank and Roper [69] demonstrated that $\Delta o x y R$ mutants negatively regulated the gene expression of exopolysaccharides, making the mutants more prone to oxidative stress. Besides providing protection against ROS and other environmental injuries, the polysaccharide component allows the cells to adhere to each other and to the surfaces [70]. In X. fastidiosa, exopolysaccharide production is fundamental to surface attachment, biofilm formation within the xylem vessels, virulence and insect transmission [71,72]. By knocking out two genes implicated in the exopolysaccharide biosynthesis in X. fastidiosa subsp. fastidiosa, Killiny et al. [73] demonstrated that mutants were severely constrained in forming biofilm, in moving through the xylem and in being transmitted by the insect, resulting in avirulent phenotypes. In contrast to polysaccharides, EPS protein significantly decreased by up to $91 \%$ in all treated biofilm, especially in the co-treatments (NAC/NAC). The disulphide breaking activity of NAC might have led to the destabilization of proteins in the EPS matrix [74].

The impact of NAC treatment on Xf-DD biofilm detachment was also examined. The results indicated that none of the NAC-based treatments increased biofilm detachment, compared to the control samples. Rather, control samples (-/-) that were further exposed to NAC became less prone to biofilm disaggregation and detachment.

Overall, our findings indicated that $500 \mu \mathrm{M}$ NAC had generated phenotypic diversification in Xf-DD biofilm, promoting biofilm formation (hyper-biofilm-forming phenotype) and discouraging biofilm detachment (hyper-attachment phenotype), while increasing oxidative stress level in the biofilm. This results are in line with a number of studies reporting how exposure to sub-lethal doses of antibiotics may enhance biofilm formation in a wide range of species $[75,76]$. Despite the undesirable effect of biofilm biomass increase, the hyper-attachment phenotype might be associated with an Xf-DD inability to migrate in xylem vessels to cause a disease. It has been proposed that $X$. fastidiosa forms a biofilm to partially attenuate its own virulence by limiting its diffusion within the plant [11]. Newman et al. [77] observed a reduced virulence in X. fastidiosa biofilm with a high degree of adhesion, which inhibited the acquisition and the transmission of pathogens by sharpshooter vectors as well as the fast 
colonization of the plant throughout the xylem vessels. Thus, this study provides some important implications on the ecology of Xf-DD biofilm, as well as how this plant pathogen should be treated.

Future works will be devoted to deciphering the mechanisms behind the non-lethal effects of NAC on Xf-DD. Further in-planta investigations are necessary to elucidate the effects of non-lethal concentrations of NAC on Xf-DD virulence.

Author Contributions: C.C., L.D.V. and F.V. conceived, designed the research and wrote the manuscript. C.C. and L.D.V. conducted the experiments. F.V. performed data analyses. F.C. and F.F. contributed critically to the drafts. G.D.A. and M.S. contributed with reagents and protocols. All authors read and approved the manuscript.

Funding: This work was partially supported by Fondazione Cariplo, grant no. 2017-0977 and by Regione Puglia (DD n. 495 del 14/10/2015 and n. 279 del 9/8/2016, Progetto di ricerca Linea B-STIPXYT).

Conflicts of Interest: The authors declare no conflict of interest. The founding sponsors had no role in the design of the study; in the collection, analyses, or interpretation of data; in the writing of the manuscript, and in the decision to publish the results.

\section{References}

1. EFSA (European Food Safety Authority). Scientific report on the update of the Xylella spp. host plant database. EFSA J. 2018, 16, 5408.

2. Delbianco, A.; Czwienczek, E.; Pautasso, M.; Kozelska, S.; Monguidi, M.; Stancanelli, G. A new resource for research and risk analysis: The updated european food safety authority database of Xylella spp. host plant species. Phytopathology 2019, 109, 213-215. [CrossRef] [PubMed]

3. Almeida, R.P.P.; Nunney, L. How do plant diseases caused by Xylella fastidiosa emerge? Plant Dis. 2015, 99, 1457-1467. [CrossRef] [PubMed]

4. Martelli, G.P.; Boscia, D.; Porcelli, F.; Saponari, M. The olive quick decline syndrome in south-east Italy: A threatening phytosanitary emergency. Eur. J. Plant Pathol. 2016, 144, 235-243. [CrossRef]

5. Cornara, D.; Bosco, D.; Fereres, A. Philaenus spumarius: When an old acquaintance becomes a new threat to European agriculture. J. Pest. Sci. 2018, 91, 957-972. [CrossRef]

6. Saponari, M.; Giampetruzzi, A.; Loconsole, G.; Boscia, D.; Saldarelli, P. Xylella fastidiosa in olive in Apulia: Where we stand. Phytopathology 2019, 109, 175-186. [CrossRef]

7. Giampetruzzi, A.; Saponari, M.; Almeida, R.; Essakhi, S.; Boscia, D.; Loconsole, G.; Saldarelli, P. Complete genome sequence of the olive-infecting strain Xylella fastidiosa subsp. pauca De Donno. Genome Announc. 2017, 5, e00569-17. [CrossRef]

8. Saponari, M.; Boscia, D.; Altamura, G.; Loconsole, G.; Zicca, S.; D’Attoma, G.; Morelli, M.; Palmisano, F.; Saponari, A.; Tavano, D.; et al. Isolation and pathogenicity of Xylella fastidiosa associated to the olive quick decline syndrome in southern Italy. Sci. Rep. 2017, 7, 17723. [CrossRef]

9. Purcell, A. Paradigms: Examples from the bacterium Xylella fastidiosa. Annu. Rev. Phytopathol. 2013, 51, 339-356. [CrossRef]

10. Mendes, J.S.; Santiago, A.S.; Toledo, M.A.; Horta, M.A.; de Souza, A.A.; Tasic, L.; de Souza, A.P. In vitro determination of extracellular proteins from Xylella fastidiosa. Front. Microbiol. 2016, 7, 2090. [CrossRef]

11. Rapicavoli, J.; Ingel, B.; Blanco-Ulate, B.; Cantu, D.; Roper, C. Xylella fastidiosa: An examination of a re-emerging plant pathogen. Mol. Plant. Pathol. 2018, 19, 786-800. [CrossRef]

12. Killiny, N.; Almeida, R.P.P.P. Factors affecting the initial adhesion and retention of the plant pathogen Xylella fastidiosa in the foregut of an insect vector. Appl. Environ. Microbiol. 2014, 80, 420-426. [CrossRef] [PubMed]

13. Cardinale, M.; Luvisi, A.; Meyer, J.B.; Sabella, E.; De Bellis, L.; Cruz, A.C.; Ampatzidis, Y.; Cherubini, P. Specific Fluorescence in Situ Hybridization (FISH) test to highlight colonization of xylem vessels by Xylella fastidiosa in naturally infected olive trees (Olea europaea L.). Front. Plant Sci. 2018, 9, 431. [CrossRef] [PubMed]

14. Bezerra-Silva, G.C.D.; Silva, M.A.; De Miranda, M.P.; Lopes, J.R.S. Effect of contact and systemic insecticides on the sharpshooter Bucephalogonia xanthophis (Hemiptera: Cicadellidae), a vector of Xylella fastidiosa in citrus. Fla Entomol. 2012, 95, 854-861. [CrossRef]

15. Virla, E.G.; Van Nieuwenhove, G.A.; Palottini, F.; Triapitsyn, S.V.; Logarzo, A.G. Spatial and seasonal distribution of egg parasitoids of the sharpshooter Tapajosa rubromarginata (Hemiptera: Cicadellidae: Proconiini) on feral Johnson grass and commercial citrus host in Argentina. Biol. Control 2019, 132, 81-88. [CrossRef] 
16. Caserta, R.; Souza-Neto, R.R.; Takita, M.A.; Lindow, S.E.; De Souza, A.A. Ectopic expression of Xylella fastidiosa rpfF conferring production of diffusible signal factor in transgenic tobacco and citrus alters pathogen behavior and reduces disease severity. Mol. Plant Microbe Interact. 2017, 30, 866-875. [CrossRef]

17. Dandekar, A.M.; Gouran, H.; Ibáñez, A.M.; Uratsu, S.L.; Agüero, C.B.; McFarland, S.; Borhani, Y.; Feldstein, P.A.; Bruening, G.; Nascimento, R.; et al. An engineered innate immune defense protects grapevines from Pierce disease. Proc. Natl. Acad. Sci. USA 2012, 109, 3721-3725. [CrossRef]

18. Ahern, S.J.; Das, M.; Bhowmick, T.S.; Young, R.; Gonzalez, C.F. Characterization of novel virulent broad-host-range phages of Xylella fastidiosa and Xanthomonas. J. Bacteriol. 2014, 196, 459-471. [CrossRef]

19. Amanifar, N.; Taghavi, M.; Salehi, M. Xylella fastidiosa from almond in Iran: Overwinter recovery and effects of antibiotics. Phytopathol. Mediterr. 2016, 55, 337-345.

20. Bleve, G.; Gallo, A.; Altomare, C.; Vurro, M.; Maiorano, G.; Cardinali, A.; D’Antuono, I.; Marchi, G.; Mita, G. In vitro activity of antimicrobial compounds against Xylella fastidiosa, the causal agent of the olive quick decline syndrome in Apulia (Italy). FEMS Microbiol. Lett. 2018, 365, fnx281. [CrossRef]

21. Navarrete, F.; De La Fuente, L. Response of Xylella fastidiosa to zinc: Decreased culturability, increased exopolysaccharide production and formation of resilient biofilms under flow conditions. Appl. Environ. Microbiol. 2014, 80, 1097-1107. [CrossRef]

22. Scortichini, M.; Chen, J.; De Caroli, M.; Dalessandro, G.; Pucci, N.; Modesti, V.; L'aurora, A.; Petriccione, M.; Zampella, L.; Mastrobuoni, F.; et al. A zinc, copper and citric acid biocomplex shows promise for control of Xylella fastidiosa subsp. pauca in olive trees in Apulia region (southern Italy). Phytopathol. Mediterr. 2018, 57, 48-72.

23. Ribeiro, A.B.; Abdelnur, P.V.; Garcia, C.F.; Belini, A.; Severino, V.G.; da Silva, M.F.; Fernandes, J.B.; Vieira, P.C.; de Carvalho, S.A.; de Souza, A.A.; et al. Chemical characterization of Citrus sinensis grafted on C. limonia and the effect of some isolated compounds on the growth of Xylella fastidiosa. J. Agric. Food Chem. 2008, 56, 7815-7822. [CrossRef] [PubMed]

24. Maddox, C.E.; Laur, L.M.; Tian, L. Antibacterial activity of phenolic compounds against the phytopathogen Xylella fastidiosa. Curr. Microbiol. 2010, 60, 53-58. [CrossRef] [PubMed]

25. Aldrich, T.J.; Rolshausen, P.E.; Roper, M.C.; Reader, J.M.; Steinhaus, M.J.; Rapicavoli, J.; Vosburg, D.A.; Maloney, K.N. Radicinin from Cochliobolus sp. inhibits Xylella fastidiosa, the causal agent of Pierce's disease of grapevine. Phytochemistry 2015, 116, 130-137. [CrossRef] [PubMed]

26. Dinicola, S.; De Grazia, S.; Carlomagno, G.; Pintucci, J.P. N-acetylcysteine as powerful molecule to destroy bacterial biofilms. A systematic review. Eur. Rev. Med. Pharmacol. Sci. 2014, 18, 2942-2948. [PubMed]

27. Moon, J.H.; Choi, Y.S.; Lee, H.W.; Heo, J.S.; Chang, S.W.; Lee, J.Y. Antibacterial effects of N-acetylcysteine against endodontic pathogens. J. Microbiol. 2016, 54, 322-329. [CrossRef]

28. Domenech, M.; García, E. N-Acetyl-1-Cysteine and cysteamine as new strategies against mixed biofilms of nonencapsulated Streptococcus pneumoniae and Nontypeable Haemophilus influenzae. Antimicrob. Agents Chemother. 2017, 61, e01992-16.

29. Muranaka, L.S.; Giorgiano, T.E.; Takita, M.A.; Forim, M.R.; Silva, L.F.; Coletta-Filho, H.D.; Machado, M.A.; de Souza, A.A. N-acetylcysteine in agriculture, a novel use for an old molecule: Focus on controlling the plant-pathogen Xylella fastidiosa. PLoS ONE 2013, 8, e72937. [CrossRef]

30. Picchi, S.C.; Takita, M.A.; Coletta-Filho, H.D.; Machado, M.A.; de Souza, A.A. N-acetylcysteine interferes with the biofilm formation, motility and epiphytic behaviour of Xanthomonas citri subsp. citri. Plant Pathol. 2016, 65, 561-569. [CrossRef]

31. Saponari, M.; Boscia, D.; Nigro, F.; Martelli, G.P. Identification of DNA sequences related to Xylella fastidiosa in oleander, almond and olive trees exhibiting leaf scorch symptoms in Apulia (Southern Italy). J. Plant Pathol. 2013, 95, 659-668.

32. Wells, J.M.; Raju, B.C.; Hung, H.Y.; Weisburg, W.G.; Mandel-co-Paul, L.; Brenner, D.J. Xylella fastidiosa gen. nov.; sp. nov.: Gram-negative, xylem-limited, fastidious plant bacteria related to Xanthomonas spp. Int. J. Syst. Bacteriol. 1987, 37, 136-145. [CrossRef]

33. Kandel, P.P.; Almeida, R.P.P.; Cobine, P.A.; De La Fuente, L. Natural competence rates are variable among Xylella fastidiosa strains and homologous recombination occurs in vitro between subspecies fastidiosa and multiplex. Mol. Plant Microbe Interact. 2017, 30, 589-600. [CrossRef] [PubMed]

34. Zaini, P.A.; De La Fuente, L.; Hoch, H.C.; Burr, T.J. Grapevine xylem sap enhances biofilm development by Xylella fastidiosa. FEMS Microbiol. Lett. 2009, 295, 129-134. [CrossRef] [PubMed] 
35. Garuglieri, E.; Meroni, E.; Cattò, C.; Villa, F.; Cappitelli, F.; Erba, D. Effects of sub-lethal concentrations of silver nanoparticles on a simulated intestinal prokaryotic-eukaryotic interface. Front. Microbiol. 2018, 8, 2698. [CrossRef] [PubMed]

36. Glasenapp, Y.; Cattò, C.; Villa, F.; Saracchi, M.; Cappitelli, F.; Papenbrock, J. Promoting beneficial and inhibiting undesirable biofilm formation with mangrove extracts. Int. J. Mol. Sci. 2019, 20, 3549. [CrossRef] [PubMed]

37. Bradford, M.M. A rapid and sensitive method for the quantitation of microgram quantities of protein utilizing the principle of protein-dye binding. Anal. Biochem. 1976, 72, 248-254. [CrossRef]

38. Schindelin, J.; Arganda-Carreras, I.; Frise, E.; Kaynig, V.; Longair, M.; Pietzsch, T.; Preibisch, S.; Rueden, C.; Saalfeld, S.; Schmid, B.; et al. Fiji: An open-source platform for biological-image analysis. Nat. Methods 2012, 9, 676-682. [CrossRef]

39. Villa, F.; Remelli, W.; Forlani, F.; Gambino, M.; Landini, P.; Cappitelli, F. Effects of chronic sub-lethal oxidative stress on biofilm formation by Azotobacter vinelandii. Biofouling 2012, 28, 823-833. [CrossRef]

40. Masuko, T.; Minami, A.; Iwasaki, N.; Majima, T.; Nishimura, S.; Lee, Y.C. Carbohydrate analysis by a phenol-sulfuric acid method in microplate format. Anal. Biochem. 2005, 339, 69-72. [CrossRef]

41. Jakubowski, W.; Bilinski, T.; Bartosz, G. Oxidative stress during aging of stationary cultures of the yeast Saccharomyces cerevisiae. Free Radic. Biol. Med. 2000, 28, 659-664. [CrossRef]

42. Blasi, F.; Page, C.; Rossolini, G.M.; Pallecchi, L.; Matera, M.G.; Rogliani, P.; Cazzola, M. The effect of $\mathrm{N}$-acetylcysteine on biofilms: Implications for the treatment of respiratory tract infections. Respir. Med. 2016, 117, 190-197. [CrossRef] [PubMed]

43. Costa, F.; Sousa, D.M.; Parreira, P.; Lamghari, M.; Gomes, P.; Martins, M.C.L. N-acetylcysteine-functionalized coating avoids bacterial adhesion and biofilm formation. Sci. Rep. 2017, 7, 17374. [CrossRef] [PubMed]

44. Pollini, S.; Di Pilato, V.; Landini, G.; Di Maggio, T.; Cannatelli, A.; Sottotetti, S.; Cariani, L.; Aliberti, S.; Blasi, F.; Sergio, F.; et al. In vitro activity of N-acetylcysteine against Stenotrophomonas maltophilia and Burkholderia cepacia complex grown in planktonic phase and biofilm. PLoS ONE 2018, 13, e0203941. [CrossRef] [PubMed]

45. Drago, L.; De Vecchi, E.; Mattina, R.; Romano, C.L. Activity of N-acetyl-L-cysteine against biofilm of Staphylococcus aureus and Pseudomonas aeruginosa on orthopedic prosthetic materials. Int. J. Artif. Organs 2013, 36, 39-46. [CrossRef]

46. Lea, J.; Conlin, A.E.; Sekirov, I.; Restelli, V.; Ayakar, K.G.; Turnbull, L.; Doyle, P.; Noble, M.; Rennie, R.; Schreiber, W.E.; et al. In vitro efficacy of N-acetylcysteine on bacteria associated with chronic suppurative otitis media. J. Otolaryngol. Head Neck Surg. 2014, 43, 20. [CrossRef]

47. Eroshenko, D.; Polyudova, T.; Korobov, V. N-acetylcysteine inhibits growth, adhesion and biofilm formation of Gram-positive skin pathogens. Microb. Pathog. 2017, 105, 145-152. [CrossRef]

48. Salta, M.; Wharton, J.A.; Dennington, S.P.; Stoodley, P.; Stokes, K.R. Anti-biofilm performance of three natural products against initial bacterial attachment. Int. J. Mol. Sci. 2013, 14, 21757-21780. [CrossRef]

49. Paytubi, S.; de La Cruz, M.; Tormo, J.R.; Martín, J.; González, I.; González-Menendez, V.; Genilloud, O.; Reyes, F.; Vicente, F.; Madrid, C.; et al. A high-throughput screening platform of microbial natural products for the discovery of molecules with antibiofilm properties against Salmonella. Front. Microbiol. 2017, 8, 326. [CrossRef]

50. Sengupta, S.; Chattopadhyay, M.K.; Grossart, H.P. The multifaceted roles of antibiotics and antibiotic resistance in nature. Front. Microbiol. 2013, 4, 47. [CrossRef]

51. Azeredo, J.; Azevedo, N.F.; Briandet, R.; Cerca, N.; Coenye, T.; Costa, A.R.; Desvaux, M.; Di Bonaventura, G.; Hebraud, M.; Jaglic, Z.; et al. Critical review on biofilm methods. Crit. Rev. Microbiol. 2017, 43, 313-351. [CrossRef]

52. Sagristá, M.L.; García, A.E.; Africa De Madariaga, M.; Mora, M. Antioxidant and pro-oxidant effect of the thiolic compounds N-acetyl-L-cysteine and glutathione against free radical-induced lipid peroxidation. Free Radic. Res. 2002, 36, 329-340. [CrossRef] [PubMed]

53. Finn, N.A.; Kemp, M.L. Pro-oxidant and antioxidant effects of N-acetylcysteine regulate doxorubicin-induced NF-kappa B activity in leukemic cells. Mol. Biosyst. 2012, 8, 650-662. [CrossRef] [PubMed]

54. Federici, M.T.; Marcondes, J.A.; Picchi, S.C.; Stuchi, E.S.; Fadel, A.L.; Laia, M.L.; Lemos, M.V.F.; Lemos, E.G.M. Xylella fastidiosa: An in vivo system to study possible survival strategies within citrus xylem vessels based on global gene expression analysis. Electron. J. Biotech. 2012, 15, 717-3458. [CrossRef] 
55. Wang, P.; Lee, Y.; Igo, M.M.; Roper, M.C. Tolerance to oxidative stress is required for maximal xylem colonization by the xylem-limited bacterial phytopathogen, Xylella fastidiosa. Mol. Plant Pathol. 2017, 18, 990-1000. [CrossRef]

56. Toledo, M.A.; Schneider, D.R.; Azzoni, A.R.; Favaro, M.T.; Pelloso, A.C.; Santos, C.A.; Saraiva, A.M.; Souza, A.P. Characterization of an oxidative stress response regulator, homologous to Escherichia coli OxyR, from the phytopathogen Xylella fastidiosa. Protein Expr. Purif. 2011, 75, 204-210. [CrossRef]

57. Singh, R.; Singh, S.; Parihar, P.; Mishra, R.K.; Tripathi, D.K.; Singh, V.P.; Chauhan, D.K.; Prasad, S.M. Reactive oxygen species (ros): Beneficial companions of plants' developmental processes. Front. Plant Sci. 2016, 27, 1299. [CrossRef]

58. Chua, S.L.; Ding, Y.; Liu, Y.; Cai, Z.; Zhou, J.; Swarup, S.; Drautz-Moses, D.I.; Schuster, S.C.; Kjelleberg, S.; Givskov, M.; et al. Reactive oxygen species drive evolution of pro-biofilm variants in pathogens by modulating cyclic-di-GMP levels. Open Biol. 2016, 6, 160162. [CrossRef]

59. Gambino, M.; Cappitelli, F. Biofilm responses to oxidative stress. Biofouling 2016, 32, 167-178. [CrossRef]

60. Oh, E.; Andrews, K.J.; Jeon, B. Enhanced biofilm formation by ferrous and ferric iron through oxidative stress in Campylobacter jejuni. Front. Microbiol. 2018, 6, 1204. [CrossRef]

61. Yin, S.; Jiang, B.; Huang, G.; Zhang, Y.; You, B.; Chen, Y.; Gong, Y.; Chen, J.; Yuan, Z.; Zhao, Y.; et al. The interaction of $\mathrm{N}$-acetylcysteine and serum transferrin promotes bacterial biofilm formation. Cell Physiol. Biochem. 2018, 45, 1399-1409. [CrossRef]

62. Ahimou, F.; Semmens, M.J.; Haugstad, G.; Novak, P.J. Effect of protein, polysaccharide, and oxygen concentration profiles on biofilm cohesiveness. Appl. Environ. Microbiol. 2007, 73, 2905-2910. [CrossRef] [PubMed]

63. Olofsson, A.C.; Hermansson, M.; Elwing, H. N-acetyl-L-cysteine affects growth, extracellular polysaccharide production, and bacterial biofilm formation on solid surfaces. Appl. Environ. Microbiol. 2003, 69, 4814-4822. [CrossRef] [PubMed]

64. Lehman, A.P.; Rugel Long, S. Exopolysaccharides from Sinorhizobium meliloti can protect against $\mathrm{H}_{2} \mathrm{O}_{2}$-dependent damage. J. Bacteriol. 2013, 195, 5362-5369. [CrossRef] [PubMed]

65. Jang, I.A.; Kim, J.; Park, W. Endogenous hydrogen peroxide increases biofilm formation by inducing exopolysaccharide production in Acinetobacter oleivorans DR1. Sci. Rep. 2016, 17, 21121. [CrossRef]

66. Svenningsen, N.B.; Martínez-García, E.; Nicolaisen, M.H.; de Lorenzo, V.; Nybroe, O. The biofilm matrix polysaccharides cellulose and alginate both protect Pseudomonas putida $\mathrm{mt}-2$ against reactive oxygen species generated under matric stress and copper exposure. Microbiology 2018, 164, 883-888. [CrossRef]

67. Tomida, H.; Yasufuku, T.; Fujii, T.; Kondo, Y.; Kai, T.; Anraku, M. Polysaccharides as potential antioxidative compounds for extended-release matrix tablets. Carbohydrate Res. 2010, 345, 82-86. [CrossRef]

68. Lin, Y.; Liu, J.; Hu, Y.; Song, X.; Zhao, Y. An antioxidant exopolysaccharide devoid of pro-oxidant activity produced by the soil bacterium Bordetella sp. B4. Bioresour. Technol. 2012, 124, 245-251. [CrossRef]

69. Burbank, L.; Roper, M.C. OxyR and SoxR modulate the inducible oxidative stress response and are implicated during different stages of infection for the bacterial phytopathogen Pantoea stewartii subsp. stewartii. Mol. Plant Microbe Interact. 2014, 27, 479-490. [CrossRef]

70. Limoli, D.H.; Jones, C.J.; Wozniak, D.J. Bacterial extracellular polysaccharides in biofilm formation and function. Microbiol. Spectr. 2015, 3. [CrossRef]

71. Chatterjee, S.; Almeida, R.P.P.; Lindow, S. Living in two worlds: The plant and insect lifestyles of Xylella fastidiosa. Annu. Rev. Phytopathol. 2008, 46, 243-271. [CrossRef]

72. Janissen, R.; Murillo, D.M.; Niza, B.; Sahoo, P.K.; Nobrega, M.M.; Cesar, C.L.; Temperini, M.L.; Carvalho, H.F.; de Souza, A.A.; Cotta, M.A. Spatiotemporal distribution of different extracellular polymeric substances and filamentation mediate Xylella fastidiosa adhesion and biofilm formation. Sci. Rep. 2015, 5, 9856. [CrossRef] [PubMed]

73. Killiny, N.; Martinez, R.H.; Dumenyo, C.K.; Cooksey, D.A.; Almeida, R.P.P. The exopolysaccharide of Xylella fastidiosa is essential for biofilm formation, plant virulence, and vector transmission. Mol. Plant Microbe Interact. 2013, 26, 1044-1053. [CrossRef] [PubMed]

74. Aldini, G.; Altomare, A.; Baron, G.; Vistoli, G.; Carini, M.; Borsani, L.; Sergio, F. N-Acetylcysteine as an antioxidant and disulphide breaking agent: The reasons why. Free Radic. Res. 2018, 52, 751-762. [CrossRef] [PubMed] 
75. Andersson, D.I.; Hughes, D. Microbiological effects of sublethal levels of antibiotics. Nat. Rev. Microbiol. 2014, 12, 465-478. [CrossRef]

76. Hoffman, L.R.; D’Argenio, D.A.; MacCoss, M.J.; Zhang, Z.; Jones, R.A.; Mill, S.I. Aminoglycoside antibiotics induce bacterial biofilm formation. Nature 2005, 436, 1171-1175. [CrossRef]

77. Newman, K.L.; Almeida, R.P.; Purcell, A.H.; Lindow, S.E. Cell-cell signaling controls Xylella fastidiosa interactions with both insects and plants. Proc. Natl. Acad. Sci. USA 2004, 101, 1737-1742. [CrossRef]

(C) 2019 by the authors. Licensee MDPI, Basel, Switzerland. This article is an open access article distributed under the terms and conditions of the Creative Commons Attribution (CC BY) license (http://creativecommons.org/licenses/by/4.0/). 